\title{
J11 ・流体の熱流動特性
}

\section{Experimental Study on Convective Heat Transfer of Aqueous Suspension of Nano-Diamonds}

\author{
○佐藤 由多加（熊本大） \\ 正 鳥居 修一（熊本大） \\ 正 井村 英昭（熊本大） \\ 正 小系 康志（熊本大） \\ Yutaka Sato, \\ Shuichi Torii, Hideaki Imura, Yasushi Koito
}

Department of Mechanical System Engineering. Kumamoto University, Kumamoto 860-8555, Japan

Key Words: Nano-Fluid, Heat Transfer, Turbulent Flow, Viscosity

\section{1. 緒䇾}

Maxwell の理論上の研究(1)が発表されて以来，微粒子を含 屯懸濁液の熱伝導率について多くの研究が行われてきた。 し かし、こ扎らの研究は精径がミリもしくはマイクロオーダー の粒子を使用したため, 犋濁波の安定性の不足や流路のつま りと侵食, 圧力損失などの問題が発生し，実用化に注至らな かった(2)。これらを解消するためにミり・マイクロ粒子より もさらに徵小な粒子「ナノ粒子」が開発された。このナノ粒 子を熱工学の分野に適用し，「ナノ流体」と呼ばれる熱伝導 率の高い作動媒体が開発された.ナノ流体 (nano-fluid) とは, 水などの作動媒体にナノオーダーの金属・非金属粒子を混合 させた新しい種類の流体のことを言う。その特徽として伝熱 面積と熱容量の増加や熱伝導率の増加などが挙げられる。

本研究では，現在知られている物質中で最も熱伝導率が高 いナノダイヤモンド粒子を媒体に混合させたナノ流体を用 い, 熱流束一定の条件のもとで円管内部熱流動実験を行い, ナノ流体の体積分率とレイノルズ数が伝熱性能に与える影 響について検討した。

\section{2. 実験装置および方法}

実験装置の概略を Fig.1 亿示す, 実験装置は冷却装置, 電 圧調整器, データロガー, 流量計, ポンプ, 電圧計, ステン レス管で構成されている。

流体を加熱試験部の流入口付近にある椧却装置で設定温 度である $20^{\circ} \mathrm{C}$ で椧却し，加熱試験部に流入させた. ステン レス管は内径 $3.96 \mathrm{~mm}$, 肉厚 $0.17 \mathrm{~mm}$, 長さ $1000 \mathrm{~mm}$ であり, 電圧調整器を用いてステンレス管に直接電圧をかけること によってジュール熱を発生させ，流体を加熱した．流入，流 出口および加熱試験部には計 8 本の $\mathrm{K}$ 型熱電対を設置してお り, 流体の流入，流出温度およびそれぞれの位置 P1 P6 の外 管壁面温度を測定した。

本研究で評価したナノ流体は，粒径 3 10nm のナノダイヤ モンド粒子を水に懸濁し，その体積分率は $0.4 \%, 1 \%$ とした。 実験におけるレイノルズ数は $R e=2650$ - 6650 の範团で测定 し，水の実験結果と比較した。

\section{3. 結果および考察}

ナノ流体の熱伝導率は次式(3)索用いて算定した。

$$
k=k_{f}\left[\frac{k_{s}+(n-1) k_{f}-(n-1) V\left(k_{f}-k_{s}\right)}{k_{s}+(n-1) k_{f}+V\left(k_{f}-k_{s}\right)}\right]
$$

ここで， $k$ は熱伝導率，Vは体積分率，添字 $f$ は基碮流体， $s$ は粒子である.また， $n$ は経験的に得られた形状係数であり， 次式で与えられる。

$$
n=\frac{3}{\phi}
$$

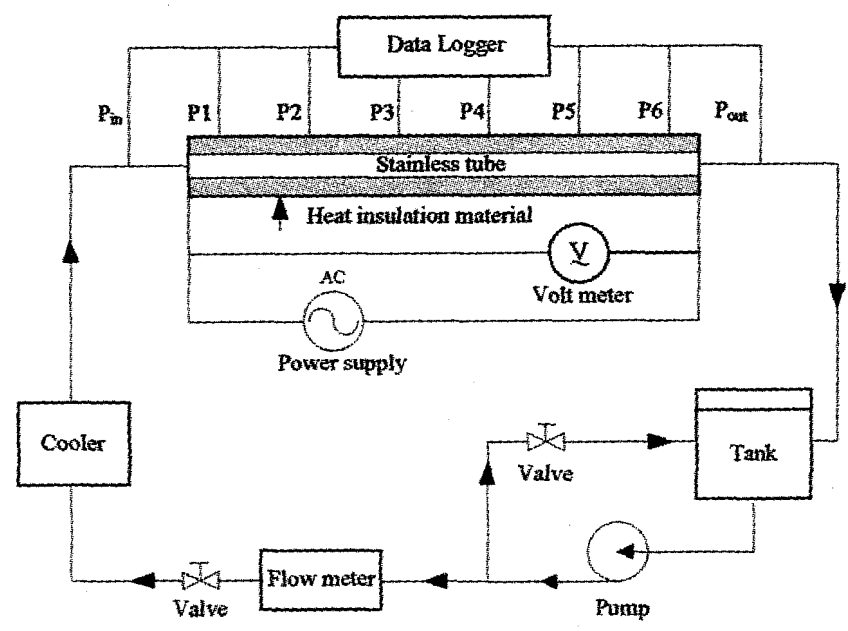

Fig.l Experimental apparatus

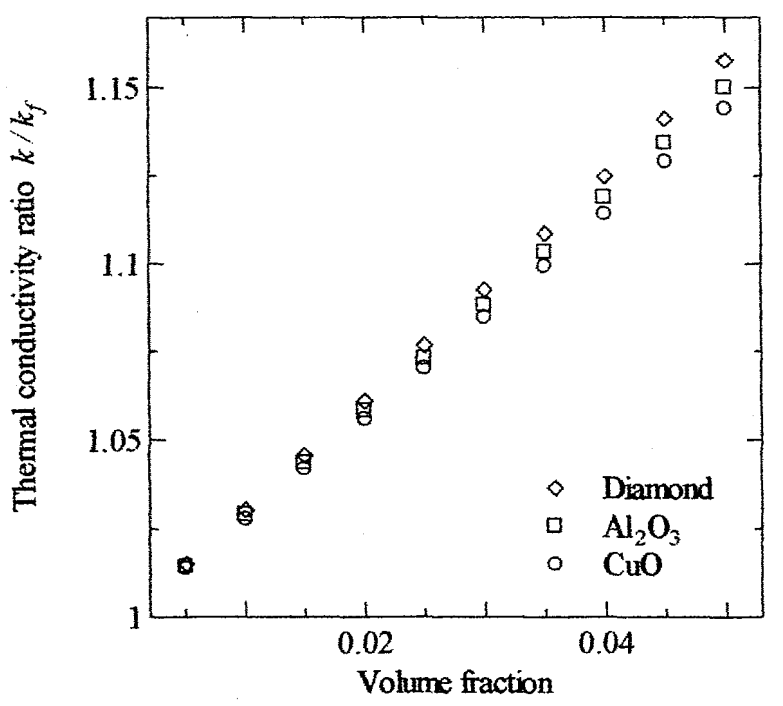

Fig.2 Effect of particle volume fraction on the thermal conductivity for different nano-fluids

ここで，фは同じ体積で球状の粒子と実際の粒子の表面積の 比として定義されている. 本研究では $n=3$ とした.

Fig.2は,各種ナノ流体の熱伝導率を比較したものである. $\mathrm{Al}_{2} \mathrm{O}_{3}$ や $\mathrm{CuO}$ と比べてダイヤモンドの熱伝導率の方が優れて いることがわかる.したがって，ダイヤモンドナノ流体怯他 のナノ流体よりも優れた伝熱性能を持っていることが期待 できる. 
ナノ粒子を加えることによって流体の粘度は增加するこ とが知られている。二相混合流体の粘度は式(3)に示す Batchelor ${ }^{(4)}$ の式により算定することができる。

$$
\eta / \eta_{\text {base }}=6.2 V^{2}+2.5 \mathrm{~V}+1
$$

ここで， $\eta$ はナノ流体の粘度， $\eta_{\text {base }}$ は基礎流体の粘度，Vは ナノ流体の体積分率である，キャノンフェンスケ粘度計を用

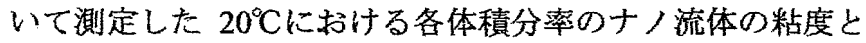
Batchelor の式により算定したナノ流体の粘度を比較した結 果を Fig.3に示す. Fig.3から明らかなように，ナノ流体の粘 度は算定した粘度よりもはるかに高いことがわかる。したが って, Batchelorの式ではナノ流体の粘度は算定することがで きないため，実験により求めなければならない。

位置 P4 $(x / D=144)$ における体積分率 $0.4 \%, 1 \%$ のナノ流体 および水の熱卮達率を Fig.4 に示吉。熱伝達率は次式を用い て求めた。

$$
h=\frac{q}{T_{w x}-T_{m x}}
$$

ここで, $h$ は熱伝達率， $q$ は熱流束， $T_{\text {wx }}, T_{\operatorname{mx}}$ は位置 $x$ にお ける内管壁面温度, 混合平均温度である。本研究で使用した ステンレス管の肉厚は非常に薄いため，外管壁面温度々内管 壁面温度は等しいものとした。

$R e$ が低い場合，水とナノ流体の熱伝達率にあまり差は見 られないが， $R e$ の増加に伴い，广ノ流体の熱后達率の方が 大きくなる傾向が見られる. $R e=5400$ 付近で体積分率が $0.4 \%$ とき，水の熱伝達率に比へて約 $6 \%$ 上昇して沾り，1\% のときは約 $14 \%$ 上昇している.

Fig.4の結果をヌセルト数 $N u$ でまとめたものを Fig.5に示 す. Nu は対流による熱伀達率と流体の熱伝導率の比率を示 す無次元数であり，次式で定義される.

$$
N u=\frac{h \cdot L}{k}
$$

ここで， $h$ は熱伝達率，Lは代表長さ， $k$ は熱伝導率である。 $R e$ の増加に伴い, ナ流体の $\mathrm{Nu}$ は増加している. 特に $R e$ の高い領域になるにつれて流体に慗濁したナノ粒子同士 の衛突頻度が向上するため，熱を持ったナノ粒子から熱を持 たないナノ粒子への熱の移動方起こる頻度が高くなり，その 結果伝熱性能が向上したと考えられる。

\section{4. 結蓄}

ナノダイヤモンド粒子を用いたナノ流体の伝熱性能につ いての流動実験を行った結果, 以下のことが明らかになった。

(1) Batchelor の式ではナノ流体の粘度は算定することができ ないため，実験により求めなければならない。

(2)十ノ流体は単相流と比心て優れた伀熱性能を示す.

(3) Re を増加させるほど流体に䀣濁したナノ粒子同士の衝突 が多く起こり，伝熱性能が向上する。

\section{参考文献}

(1)Maxwell, J.C., "A Treatise on Electricity and Magnetism, 2nd Ed.", Clarendon Press, Oxford, U.K. vol.1, (1881) pp.435

(2)S. Zeinali Heris, S.Gh. Etemad, M. Nasr Esfahany "Experimental investigation of oxide nanofluids laminar flow"convective heat transfer International Communications in Heat and Mass Transfer vol.33, (2006) pp.529-535

(3)Hamilton, R.L., Crosser, O.K., "Thermal Conductivity of Heterogeneous Two-Component Systems." I\&EC Fundamentals vol.1, (1962) pp.182-191

(4)Batchelor, G., "The effect of Brownian motion on the bulk stress in a suspension of spherical particles." J.Fluid.Mech. vol.83, (1977) 1, pp.97

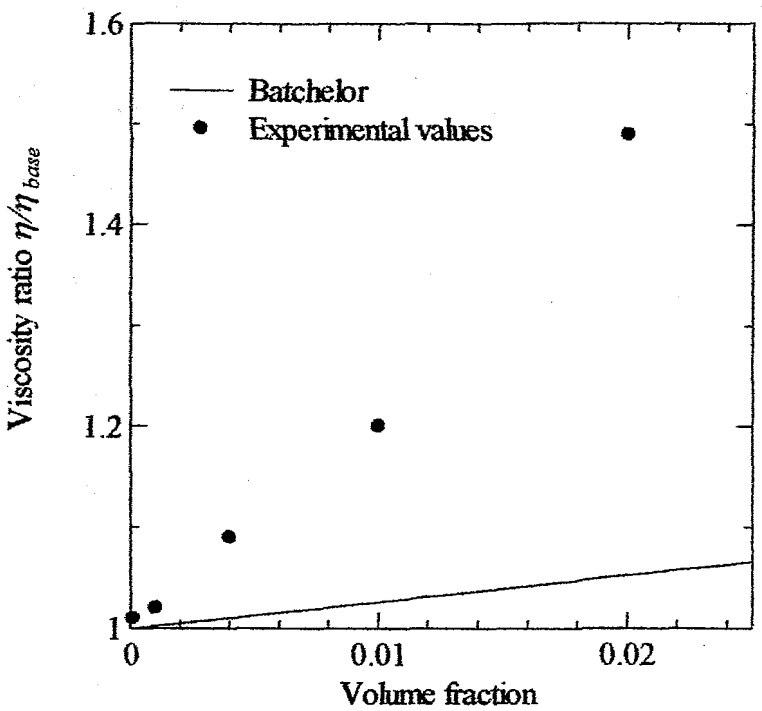

Fig.3 Comparison between experimental values and theoretical values on viscosity

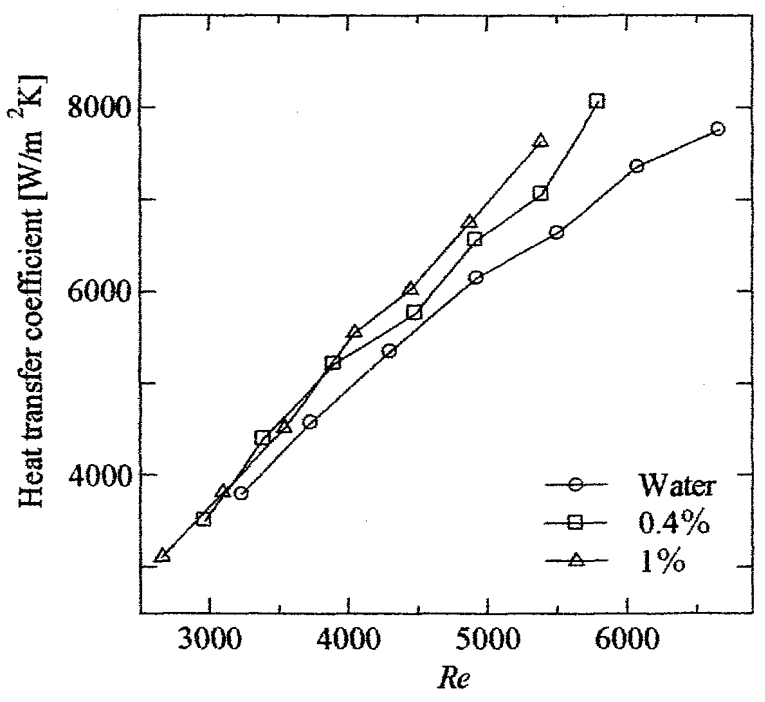

Fig.4 Heat transfer coefficient of water and nano-fluid at P4 $(x / D=144)$

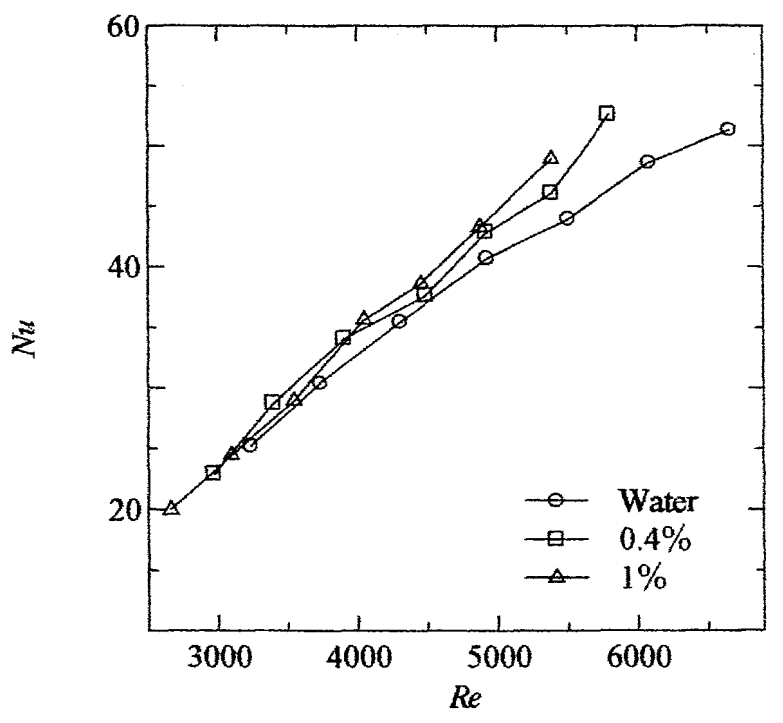

Fig.5 Nusselt numbers of water and nano-fluid at P4 $(x / D=144)$ 